\title{
PENGIMPUTASIAN KEBENARAN KRISTUS: AJARAN ALKITAB ATAU PENALARAN DOGMATIS
}

\author{
Dick Mak \\ Reformed Netherland Church of Groningen
}

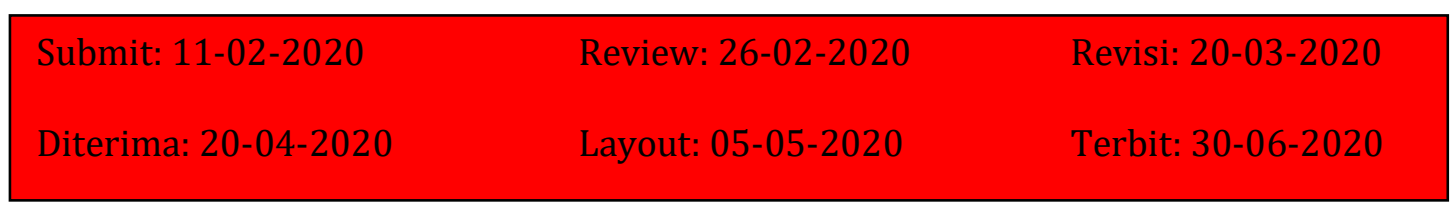

\begin{abstract}
Discussions about the meaning of imputation play an important role in the spirtuality of believers. This research attempts to show the meaning of justification in the Christians life of believers as imputation of Christ's truth. The Lord Jesus did not sin at all in his life. So, the truth refers to right behavior or life, not to status. This research examines how the development of thought in the modern age has made significant contributions to Christianity. This view stems from a new approach to Paul's theology, called The New Perspective on Paul. This research shows how faith is a means of imputing that truth. In Romans 4 the truths which are accounted for to the believer are not explained further. But in Philippians 3: 9 and 2 Corinthians 5:21 we find the terms "righteousness of God" and "righteousness which comes from God". These two passages lend support to the dogmatic term iustitia aliena, 'foreign' truth, which does not originate with the believer himself.
\end{abstract}

Keywords: Pauline Theology, Justification, Justification, New Perspective of Paul, Faith in Christ.

\begin{abstract}
Abstrak
Diskusi mengenai makna imputasi memainkan peran penting dalam pertumbuhan iman orang percaya. Penelitian ini berusaha menunjukkan bagaimana makna pembenaran dalam kehidupan spiritualitas orang percaya sebagai pengimputasian kebenaran Kristus. Tuhan Yesus tidak berdosa sama sekali seumur hidup. Jadi, kebenaran itu menunjuk kepada kelakuan atau kehidupan benar, bukan kepada status. Penelitian ini membahas tentang bagaimana perkembangan pemikiran di abad modern memberikan sumbangsih yang berarti bagi kekristenan. Pandangan ini berasal dari pendekatan baru terhadap teologi Paulus, yang disebut The New Perspective on Paul. Penelitian ini menunjukkan bagaimana iman sebagai sarana pengimputasian kebenaran itu. Dalam Roma 4 kebenaran yang diperhitungkan kepada orang percaya tidak dijelaskan lebih lanjut. Tetapi dalam Filipi 3:9 dan 2 Korintus 5:21 kita menemukan istilah 'kebenaran Allah' dan 'kebenaran yang berasal dari Allah'. Kedua nas ini memberi dukungan bagi istilah dogmatis iustitia aliena, kebenaran 'asing', yang bukan berasal dari orang percaya sendiri.
\end{abstract}

Kata Kunci: Teologi Paulus, Pembenaran, Dibenarkan, New Perpespective of Paul, Iman dalam Kristus. 


\section{Pendahuluan}

\section{Perdebatan Sekitar Ajaran Pembenaran}

Dalam teologi Reformed doktrin pembenaran diberi posisi yang sentral. Di dalamnya dua semboyan Reformasi memainkan peranan penting, yaitu Sola Gratia dan Sola Fide. Prinsip Sola Gratia diungkapkan sejelas-jelasnya dalam pembenaran. Setiap orang yang percaya dibenarkan 'oleh kasih karunia', 'dengan cuma-cuma', 'karena penebusan dalam Kristus Yesus' (Rm. 3:24). Hanya karena kasih karunia Allah kita dibenarkan, secara gratis, tanpa sumbangan apa pun dari pihak manusia. Dasar pembenaran bukan perbuatan manusia, melainkan karya Kristus. Prinsip Sola Fide (hanya oleh iman) bahkan lebih nyata lagi. Sebab tambahan 'oleh iman'atau 'karena iman' sering ditambahkan kepada kata 'pembenaran' atau 'membenarkan' atau 'dibenarkan' dalam Perjanjian Baru (PB), lihat terutama Roma 3:21-4:25. Dalam 3:21-26 Paulus menjelaskan secara singkat ajaran pembenaran oleh iman, tetapi setelah itu ia menyumbangkan satu fasal lebih kepada prinsip iman (3:27-4:25). Pada saat yang sama, doktrin pembenaran yang dianggap begitu penting sangat diperdebatkan. Berbagai aspek dari doktrin pembenaran yang dulu dianggap pasti, sekarang ini diragukan atau pun ditolak. Misalnya mengenai konteks ajaran pembenaran.

Secara tradisional ajaran pembenaran ditempatkan dalam konteks masalah dosa dan keselamatan individual. Dalam Roma 1:18-3:20 Paulus menggambarkan masalah seluruh umat manusia, termasuk orang Yahudi: tidak seorang pun dapat dibenarkan oleh perbuatan-perbuatannya, bahkan tidak oleh perbuatan-perbuatan hukum Taurat. Orang bukan Yahudi terbelenggu oleh kuasa dosa, dan mereka sendiri tidak bisa mengatasi masalah ini. Tetapi orang Yahudi pun tidak dapat diselematkan oleh usaha mereka sendiri, walaupun mereka memiliki hukum Taurat. Sebab hukum Taurat itu harus ditaati, dan sejarah bangsa Israel dan praktek hidup pada zaman Paulus sendiri membuktikan bahwa orang Yahudi pun dikuasai oleh dosa. Jadi, Paulus menyimpulkan: 'Sebab tidak seorang pun yang dapat dibenarkan di hadapan Allah oleh karena melakukan hukum Taurat, karena justru oleh hukum Taurat orang mengenal dosa' (Rm. 3:20). Tetapi sekarang ini banyak teolog berpendapat bahwa yang dimaksudkan Paulus bukan (saja) keselamatan individual, melainkan (terutama) perluasan bangsa Allah. Pandangan ini berasal dari pendekatan baru terhadap teologi Paulus, yang disebut The New Perspective on Paul. ${ }^{1}$

Istilah 'perbuatan hukum Taurat' (erga tou nomou) tidak menunjuk kepada seluruh hukum Taurat, tetapi hanya kepada 'identity markers' seperti sunat, Sabat, dan hukumhukum makanan. Yang dimaksudkan dengan ajaran tentang pembenaran adalah bahwa sekarang ini bukan saja orang Yahudi termasuk umat perjanjian, melainkan seluruh umat manusia dapat menjadi anggota bangsa Allah. Menurut James D. G. Dunn, dalam suratnya kepada jemaat di Roma Paulus ingin menerapkan janji-janji dan hukum Taurat kepada semua orang, bukan saja kepada orang Yahudi. Dalam Roma 2 dengan sengaja Paulus membahas hal-hal yang membedakan bangsa Yahudi dari bangsa-bangsa lain. Roma 12:1-15:6 harus dianggap sebagai usaha Paulus untuk memberi arti baru kepada

\footnotetext{
${ }^{1}$ Secara singkat dapat dikatakan tentang The New Perspective on Paul, bahwa pendekatan surat-surat Paulus ini menunjuk kepada penilaian tertentu dari Yudaisme abad pertama. Yudaisme itu tidak bersifat legalistis semata-mata, seolah-olah manusia bisa diselamatkan berdasarkan perbuatan-perbuatan baik yang ia lakukan. Menurut E. P. Sanders dalam bukunya Paul and Palestinian Judaism (1977), Yudaisme justru bertitik tolak dari anugerah Allah. Allah telah memilih Israel dan mendirikan perjanjian dengan mereka. Hubungan perjanjian itu diatur oleh hukum Taurat, bukan sebagai persyaratan untuk masuk ke perjanjian itu, atau mendapatkan upah, melainkan sebagai cara untuk hidup di dalam perjanjian itu. Istilah yang Sanders pakai untuk hal ini adalah covenantal nomism, yang berarti bahwa bangsa Israel harus mempertahankan statusnya sebagai bangsa pilihan Allah di tengah-tengah bangsa-bangsa lain dengan menaati hukum Taurat yang diberikan Allah sebagai sebagian dari hubungan perjanjian itu.
} 
hukum Taurat sebagai hukum bagi seluruh bangsa Allah (termasuk orang bukan Yahudi). ${ }^{2}$ Pandangan ini mempengaruhi interpretasi ajaran pembenaran. Dalam bukunya The Justice of God (hlm. 17-29), Dunn menjelaskan bahwa ajaran Paulus tentang pembenaran tidak persis sama dengan ajaran Martin Luther tentang pembenaran. Dalam surat-suratnya kepada Galatia dan Roma, Paulus membuktikan bahwa berkat-berkat perjanjian Allah diberikan kepada orang Yunani (bukan Yahudi) sama seperti kepada orang Yahudi. Allah menerima orang Yunani sebagai orang Yunani, tanpa menuntut bahwa mereka harus menjadi orang Yahudi lebih dahulu. 'The Christian doctrine of justification by faith begins as Paul's protest not as an individual sinner against a Jewish legalism, but as Paul's protest on behalf of Gentiles against Jewish exclusivism'. 'Justification by faith is Paul's fundamental objection to the idea that God has limited his saving goodness to a particular people'. ${ }^{4}$

Menurut Dunn, pada masa kini kita perlu memahami lagi ajaran Paulus yang asli tentang pokok ini. Allah menerima semua orang yang percaya kepada-Nya: orang Yunani dan orang Yahudi, orang berkulit hitam dan orang berkulit putih, orang Palestin dan orang Israel, dan sebagainya. Pandangan ini cukup berpengaruh sekarang ini. Di samping Dunn, pandangan ini, dengan beberapa variasi, dibela oleh N. T. Wright, yang sudah menulis banyak buku, dan antara lain sebuah buku tentang pembenaran. ${ }^{5}$ Pada saat yang sama cukup banyak buku diterbitkan yang membela pandangan tradisional, lihat misalnya The Future of Justification oleh John Piper6. Dalam buku ini Piper secara khusus memberi respon terhadap pandangan N.T. Wright, yang ditanggapi lagi oleh Wright dalam bukunya Justification.

\section{Pengimputasian Kebenaran Kristus}

Salah satu pokok lain sekitar pembenaran oleh iman yang diperdebatkan adalah pengimputasian kebenaran Kristus. Dalam tulisan ini saya mau berfokus kepada pokok itu. Sejak abad Reformasi pengimputasian kebenaran Kristus ini dianggap sebagai aspek mutlak dari pembenaran oleh iman. Tetapi dalam kalangan The New Perspective on Paul dan di luarnya pandangan tradisional mengenai pokok ini tidak dipertahankan lagi, atau bahkan ditolak sama sekali karena dianggap tidak mempunyai dasar alkitabiah. Dalam pandangan tradisional pembenaran adalah konsep forensik, yaitu harus ditempatkan dalam konteks pengadilan. Dalam pembenaran seorang dinyatakan tidak bersalah. Martin Luther berpendapat bahwa kebenaran datang dari luar, dan bahwa kebenaran itu menjadi milik orang percaya melalui pengimputasian ilahi. Walaupun pemikiran Luther tentang pokok pembenaran tidak begitu sistematis dan jelas, menurut Bruce McCormack dapat disimpulkan bahwa Luther bukan saja mengajarkan bahwa dosa tidak diimputasikan, melainkan juga bahwa ada pengimputasi-an positif, yaitu pengimputasian kebenaran Kristus. ${ }^{7}$ Tetapi Luther begitu mengutamakan fungsi iman, sehingga iman itu diberinya tempat yang lebih penting dari pada pengimputasian. Pengimputasian kebenaran Kristus harus memperlengkapi iman yang tidak sempurna. ${ }^{8}$

\footnotetext{
2 James D. G. Dunn, Romans 1-8 (Word Biblical Commentary 38a/B) (Dallas: Word Books, 1988), lxiiilxxii.

3 James D. G. Dunn and Alan M. Suggate, The Justice of God: A Fresh Look at the Old Doctrine of Justification by Faith (Grand Rapids: Eerdmans, 1993), 25.

4 Ibid., 28.

5 N. T. Wright, Justification: God's Plan \& Paul's Vision (Downers Grove: IVP Academic, 2009).

6 John Piper, The Future of Justification: A Response to N. T. Wright (Wheaton: Crossway Books, 2007).

7 Bruce L. McCormack, What's at Stake in Current Debates over Justification, 2003, 93.

8 Ibid., 94.
} 
Di samping itu, jawaban Luther atas pertanyaan apa itu, kebenar-an Kristus, kurang jelas. Apakah kebenaran itu adalah kebenaran yang Kristus miliki karena natur-Nya yang ilahi, atau karena Dia menjalankan hidup yang taat ketika Dia berada di dunia ini sebagai manusia? ${ }^{9}$ Menurut John Calvin, seorang dapat dibenarkan oleh iman jikalau ia, walaupun ia tidak mempunyai kebenaran berdasarkan perbuatan, menerima kebenaran Kristus oleh iman. Dengan demikian ia dapat menghadap Allah bukan sebagai orang berdosa, melainkan sebagai orang benar. 'Therefore, we explain justification simply as the acceptance with which God receives us into his favor as righteous men. And we say that it consists in the remission of sins and the imputation of Christ's righteousness.' 10 Dalam definisi ini pengimputasian kebenaran Kristus merupakan bagian mutlak dari pembenaran. Di satu pihak kita dibebaskan dari dosa-dosa kita, di pihak lainnya kita menerima kebenaran Kristus. Itu berarti bahwa pembenaran bersisi dua: dosa-dosa tidak diperhitungkan (sisi 'negatif'), yaitu pengampunan dosa, sedangkan yang diperhitungkan justru kebenaran Kristus (sisi 'positif'). Dasar bagi pengampunan dosa adalah pengimputasian kebenaran Kristus. Dengan demikian Hakim yang adil tetap adil ketika Dia mengampuni orang-orang berdosa, sebab mereka sudah dikenakan-Nya dengan kebenaran Kristus. Karena itu, dasar bagi pembenaran adalah kebenaran yang 'asing' (alien righteousness), yang bukan berasal dari manusia sendiri, melainkan dari Kristus. ${ }^{11}$

Bagi Calvin, sama seperti kebenaran Kristus diperhitungkan kepada kita, demikian juga kesalahan yang harus dihukum ditransfer kepada Kristus. Telah terjadi pertukaran yang luar biasa: Kristus mengambil alih kesalahan karena dosa kita, dan sebagai akibatnya mengenakan kebenaran-Nya yang Ia miliki kepada kita, sehingga kita dibebaskan dari hukuman. Pertukaran ini terjadi melalui pengimputasian. ${ }^{12}$ John Piper telah menulis sebuah buku khusus tentang pokok ini. Tujuan buku itu adalah untuk membuktikan bahwa Kristus menjadi pengganti kita dalam dua arti: 'In his suffering and death he becomes our curse and condemnation (Gal. 3:13; Rom. 8:3). And in his suffering and life he becomes our perfection (2 Cor. 5:21). ${ }^{13}$ Kematian Kristus bukan saja memperdamaikan murka Allah bagi kita, melainkan juga merupakan klimaks hidup kebenaran yang sempurna, yang diimputasikan kepada kita. Menurut Piper, mempertahankan doktrin pengimputasian kebenaran Kristus sangat penting. Pertamatama ia menunjuk kepada 'pastoral preciousness' dari doktrin ini. Sebab kebenaran kita sebagai orang Kristen tidak sempurna, sedangkan tuntutan untuk hidup taat tetap ada dan bersifat absolut. Allah hanya mau menerima kita berdasarkan kebenaran yang sempurna.

Di tengah-tengah kegagalan dan ketidaksempurnaan, kita boleh yakin bahwa kebenaran Kristus yang sempurna telah diimputasikan kepada kita. Bukan saja dosa kita diampuni, melainkan juga kebenaran Kristus dan kesucian-Nya yang sempurna dianggap Allah sebagai milik kita, 'seolah-olah aku sendirilah yang mengerjakan segala ketaatan yang dikerjakan oleh Kristus' untuk kita ( $\left.\mathrm{KH}^{14} \mathrm{Mi} .23, \mathrm{p} / \mathrm{j} .60\right)$. Ajaran ini merupakan 'a mighty antidote to despair for the saints'. ${ }^{15}$ Di samping itu, doktrin ini

\footnotetext{
9 Ibid., 94-95.

10 John Calvin, Institutes of the Christian Religion, Buku III. Xi. 2., n.d.

11 Demikianlah penjelasan pandangan Calvin oleh Bruce L. McCormack, Justitia Aliena: Karl Barth in Conversation with the Evangelical Doctrine of Imputed Righteousness, dalam Bruce L. McCormack (editor), Justification in Perspective: Historical Developments and Contemporary Challenges, (Grand Rapids: Baker Academic, 2006), pp. 170-72.

12 McCormack, What's at Stake in Current Debates over Justification, 98.

${ }^{13}$ John Piper, Counted Righteous in Christ: Should We Abandon the Imputation of Christ's Righteousness? (Wheaton: Crossway Books, 2002), 41.

14 Katekismus Heidelberg.

15 Piper, Counted Righteous in Christ: Should We Abandon the Imputation of Christ's Righteousness?, $122-125$.
} 
memberi penghormatan yang sepenuhnya kepada Kristus, yang layak Ia terima. Kristus bukan saja harus dimuliakan sebagai yang telah mati bagi dosa kita, dan sebagai yang mengerjakan iman dan ketaatan di dalam diri kita, melainkan juga sebagai yang menyediakan kebenaran yang sempurna bagi kita sebagai dasar penerimaan yang sepenuhnya oleh Allah. ${ }^{16}$ Tetapi tidak semua teolog Protestan menerima pandangan ini. Menurut Johannes Piscator, ketaatan Kristus yang aktif tidak bisa diimputasikan secara langsung kepada orang percaya, karena orang percaya sendiri masih wajib untuk menaati hukum Allah. Memang ketaatan Kristus yang aktif ini penting, sebab tanpa ketaatan itu kematian Kristus tidak cukup (satisfactory). Tetapi kebenaran itu tidak bisa diimputasikan kepada orang percaya. ${ }^{17}$

Menurut Robert H. Gundry ${ }^{18}$, tidak ada dasar Alkitab bagi ajaran bahwa kebenaran Kristus diimputasikan kepada kita. Dalam Galatia 3 dan Roma 4, di mana Paulus menulis tentang iman yang diperhitungkan kepada orang percaya sebagai kebenaran, atau tentang kebenaran yang diperhitungkan, tidak ada petunjuk sama sekali kepada kebenaran Kristus. Gundry meringkaskan pendapatnya sebagai berikut: manusia dapat memperoleh kebenaran di dalam Kristus, dan kebenaran itu adalah kebenaran Allah. Kebenaran itu terdiri atas iman yang diperhitungkan Allah sebagai kebenaran. Pengimputasian itu tidak bertentangan dengan murka Allah terhadap dosa kita, sebab Kristus telah ditentukan-Nya sebagai jalan pendamaian. ${ }^{19}$ Apa signifikansi penolakan pengimputasian kebenaran Kristus ini? 'Paulus tidak mengimbangkan pengimputasian dosa kita kepada Kristus dengan suatu pengimputasian kebenaran Kristus kepada kita orang percaya sebab ia (Paulus) hendak menekankan ketaatan hidup kebenaran yang harus kita jalankan ... dan penghakiman perbuatan kita pada akhir zaman'. ${ }^{20}$

Jadi, kita sudah menemukan dua keberatan terhadap ajaran pengimputasian kebenaran Kristus: (1) Tidak ada dasar alkitabiah, dan (2) ajaran ini dapat memperlemah kewajiban untuk menaati hukum-hukum Allah. Di samping itu masih bisa disebut keberatan lain: (3) ajaran ini menganggap ketaatan aktif Kristus sebagai dasar keselamatan, sehingga dasar yang sebenarnya, yaitu penderitaan Kristus, diabaikan. ${ }^{21}$ Juga Wright tidak melihat dasar alkitabiah bagi ajaran pengimputasian kebenaran Kristus. Wright bertitik tolak dari pengertian istilah dikaiosune theou sebagai kebenaran Allah sendiri, bukan sebagai kebenaran yang dianugerahkan kepada orang percaya. Istilah ini menunjuk kepada kesetiaan Allah terhadap perjanjian-Nya. ${ }^{22}$

Kata 'benar' (dikaios) dipakai untuk orang percaya dalam konteks pengadilan, dan kata ini tidak menunjuk kepada sifat moral tetapi kepada status yang diperoleh setelah putusan bebas oleh hakim. Itu berarti bahwa kebenaran (dikaiosunē) yang diperhitungkan kepada orang percaya bukanlah kebenaran Allah atau kebenaran Kristus, melainkan status baru sebagai 'anggota perjanjian' dan 'orang berdosa yang

16 Ibid., 125.

${ }^{17}$ Alister E. McGrath, Iustitia Dei: A History of the Christian Doctrine of Justification (Third Edition) (Cambridge: Cambridge University Press, 2005), 272.

18 Lihat Robert H. Gundry, "The Nonimputation of Christ's Righteousness," in Justification: What's at Stake in the Current Debates, ed. Mark Husbands and Daniel J. Treier (Downers Grove: InterVarsity Press, 2004), 17-45.

19 Ibid., 43.

20 Ibid., 44.

21 Anthony A. Hoekema, Diselamatkan Oleh Anugerah (Saved by Grace), Revisi. (Surabaya: Momentum, 2006), 242. Hoekema sendiri tidak setuju dengan keberatan ini, yang diambilnya dari A.M. Hills, Christian Theology.

22 Wright, Justification: God's Plan \& Paul's Vision; N. T. Wright, The Letter to the Romans: Introduction, Commentary, and Reflections, Dalam The New Interpreter's Bible (Volume X) (Nashville: Abingdon Press, 2002); N. T. Wright, "New Perspectives on Paul," in Justification in Perspective: Historical Developments and Contemporary Challenges, ed. Bruce L. McCormack (Grand Rapids: Baker Academic, 2006). 
dibenarkan'. ${ }^{23}$ Kebenaran itu bukan 'kebaikan moral'. Frase 'iman diperhitungkan sebagai kebenaran' berarti bahwa iman merupakan lencana atau tanda, yang menyatakan status seseorang sebagai anggota perjanjian. ${ }^{24}$ 'Allah memperhitungkan kebenaran kepadanya bukan berdasarkan perbuatannya' (Rm. 4:6) mempunyai arti yang sama dengan 'kesalahannya tidak diperhitungkan Tuhan kepadanya' (Rm. 4:8). Menurut Wright, perjanjian didirikan untuk menyelesaikan masalah dosa. Jadi, 'mengampuni dosa' sama dengan 'memperhitung-kan seseorang sebagai anggota perjanjian'.25

\section{Metode Penelitian}

Artikel ini merupakan penelitian kualitatif dengan menggunakan pendekatan literatur. Secara deskriptif berbagai sumber yang berkaitan dengan tema ini menjadi penopang dalam proses mencari jawaban atas rumusan masalah ini. Penulis akan mengulas beberapa kitab dipadukan dengan buku-buku. Pembahasan ini akan berfokus pada beberapa buku yang memang secara mendalam membahas masalah yang ada dalam artikel yang diteliti oleh penulis. Buku-buku tersebut akan memiliki peranan yang penting. Penulis akan berinteraksi dengan beberapa pemahaman dari setiap buku tersebut.

\section{Pembahasan}

\section{A. Dasar alkitabiah}

Dalam tulisan ini, saya ingin berfokus kepada keberatan pertama, yaitu dasar alkitabiah. Apakah memang benar bahwa dasar itu tidak ada, dan bahwa ajaran pengimputasian kebenaran Kristus berdasarkan tafsiran yang salah atau pemikiran teologis yang tidak berdasarkan Alkitab? Mari kita memperhatikan beberapa nas yang memainkan peran yang penting dalam diskusi ini.

\section{Roma 4 dan Galatia 3}

Paulus menggunakan dua cara untuk mengungkapkan gagasanyan bahwa kebenaran (apa pun artinya) menjadi bagian orang percaya. (1) Iman diperhitungkan (Allah) kepadanya (yaitu kepada Abraham atau orang percaya) sebagai kebenaran (Gal. 3:6; Rm. 4:3, 5, 9, 22-24); (2) Allah memperhitungkan kebenaran kepadanya (bukan berdasarkan perbuatan-nya) (Rm. 4:6), atau 'kebenaran diperhitungkan kepada mereka' (Rm. 4:11). Robert Gundry menekankan bahwa dari ayat-ayat ini tidak satu pun mengajarkan bahwa kebenaran Kristus diperhitungkan. Selain Roma 4:6 dan 11, yang diperhitungkan bukan kebenaran, melainkan iman sebagai kebenaran. Dan kebenaran ini tidak disebut kebenaran Kristus; Kristus digambarkan sebagai objek iman, seperti dalam Gal.2:16. ${ }^{26}$ Menurut Gundry, dalam frase 'iman diperhitungkan sebagai kebenaran', iman tidak bisa ditafsirkan secara instrumental, seolah-olah iman itu adalah sarana untuk memperoleh kebenaran. Interpretasi instrumental juga tidak mungkin dalam ayat-ayat lain yang memakai istilah logizomai eis (dan antara lain Rm. 2:26; 9:8; 2 Kor. 12:6; Kis. 19:27; Yak. 2:23; Kej. 15:6; Mzm. 106:31). Justru kedua hal itu, yaitu apa

23 Wright, "New Perspectives on Paul," 252-53.

24 Wright, The Letter to the Romans: Introduction, Commentary, and Reflections, Dalam The New Interpreter's Bible (Volume X), 491.

25 Ibid., 493.

${ }^{26}$ Gundry, "The Nonimputation of Christ's Righteousness," 18. 
yang diperhitungkan dan sebagai $a p a$ hal itu diperhitungkannya, dianggap identik (misalnya bukan sunat identik dengan sunat, Roma 2:26; anak-anak perjanjian identik dengan keturunan, Rm. 9:8).

Identifikasi ini berlaku bahkan kalau kedua hal itu sebenarnya sama sekali tidak sama (bukan sunat tidak sama dengan sunat). ${ }^{27}$ Dalam Galatia 3 dan Roma 4 tidak ada petunjuk sama sekali kepada kebenaran Kristus. Menurut Gundry, hal itu adalah 'confirms this linguistic conclusion that the counting of faith of righteousness is not shorthand for faith as the instrument by which an alien righteousness - Christ's - is received'. ${ }^{28}$ Memang objek iman yang diperhitungkan sebagai kebenaran adalah Kristus. Tetapi Gundry menekankan bahwa yang diperhitungkan adalah iman dalam Kristus, bukanlah Kristus sebagai objek iman. ${ }^{29}$ Penolakan fungsi instrumental dari iman tidak berarti bahwa iman dianggap sebagai perbuatan. Sebab iman adalah pemberian, bukan perbuatan (Flp. 1:29; Rm. 10:17; 12:3). Dan iman justru dipertentangan dengan perbuatan. Paulus menekankan bahwa bukan perbuatan adalah kebenaran orang percaya (lihat misalnya Flp. 3:9), melainkan imannya. ${ }^{30}$

Sebelum kita menanggapi pandangan Gundry ini, pertama-tama kita harus menentukan apa yang dimaksudkan dengan kata 'kebenaran' (dikaiosunē)? Kata ini bisa mempunyai arti etis (kelakuan atau perbuatan benar) atau arti forensik. Menurut Douglas Moo pada umumnya jelas dari konteksnya arti mana yang dimaksudkan. Ia berpendapat bahwa hampir pasti kata dikaiosunē dalam Roma 4 yang dikaitkan dengan Kejadian 15:6, dan dalam Roma 9:30-10:13 dipakai dalam arti forensik belaka, sedangkan dalam Roma 6 artinya kemungkinan besar adalah etis. ${ }^{31}$ Arti forensik itu didukung oleh pemakaian kata kerja logizomai, 'memperhitungkan', yang menurut Moo menunjuk kepada status atau posisi yuridis, yang diperhitungkan kepada seseorang (lihat 2 Sam. 19:20; Mzm. 106:31; Kej. 31:15; Mzm. 32:2). ${ }^{32}$

Seperti sudah dijelaskan di atas, Wright juga berpendapat bahwa kata 'kebenaran' dan 'benar' menunjuk kepada status, bukan kepada 'kebaikan moral', atau perbuatan baik. Hanya bagi Wright status itu adalah status sebagai anggota perjanjian. Tafsiran ini berdasarkan pengertian istilah 'kebenaran Allah' sebagai kesetiaan Allah terhadap perjanjian-Nya dan pendapatnya bahwa ajaran pembenaran terutama berfungsi sebagai bukti bahwa sekarang ini semua orang dapat menjadi anggota perjanjian, bukan saja orang Yahudi lagi. Berbeda dengan pendapat ini, lebih baik untuk mengartikan 'kebenaran' sebagai status orang yang dinyatakan benar. Jikalau yang diperhitungkan kepada kita adalah status baru, yaitu status sebagai orang benar, apakah itu berarti bahwa tidak mungkin untuk menafsirkan kebenaran itu sebagai kebenaran Kristus? Sebab dengan kebenaran Kristus sering dimaksudkan ketaatan-Nya yang sempurna kepada hukum Taurat selama kehidupan-Nya sebagai manusia di dunia ini. Tuhan Yesus tidak berdosa sama sekali seumur hidup. Jadi, kebenaran itu menunjuk kepada kelakuan atau kehidupan benar, bukan kepada status.

Menurut saya, berdasarkan ungkapan 'iman diperhitungkan sebagai kebenaran' sendiri tidak bisa disimpulkan bahwa yang dimaksudkan adalah kebenaran Kristus atau 'ketaatan-Nya yang aktif' yang diperhitungkan kepada orang percaya. Memang benar

${ }^{27}$ Ibid., 19-22.

28 Ibid., 22.

${ }^{29}$ Ibid., 22-23.

30 Ibid., 23-25.

31 Douglas J. Moo, The Epistle to the Romans (The New International Commentary on the New Testament) (Grand Rapids: Eerdmans, 1996), 88. n. 41. Lihat juga p. 262: 'Abraham's response to God's promise leads God to 'reckon' to him a 'status' of righteousness.'

${ }^{32}$ Ibid., 262. n.35. 
apa yang dikatakan Gundry, bahwa Paulus tidak berbicara secara langsung tentang kebenaran atau ketaatan Kristus dalam Roma 4. Sebentar lagi kita akan melihat apakah mungkin ada nas-nas lain yang mengungkapkan pikiran itu, sehingga dalam terang nasnas itu kita bisa berbicara tentang pengimputasian kebenaran Kristus. Tetapi sebelumnya kita harus memperhatikan beberapa hal yang bisa disimpulkan dari Roma 3 dan 4. Pertama-tama kita dapat menyimpul-kan bahwa kebenaran yang dianugerahkan kepada orang percaya adalah kebenaran yang tidak berasal dari manusia sendiri, tetapi dari Allah (iustitia aliena, kebenaran 'asing', yang berasal dari pihak lain). ${ }^{33}$ Sebab kebenaran itu diperhitungkan 'menurut kasih karunia' (LAI 'sebagai hadiah') (Rm. 4:4), kepada seseorang yang tidak bekerja (Rm. 4:5). Allah membenarkan orang durhaka (Rm. 4:5). Justru perbuatan orang yang dibenarkan adalah pelanggaran dan dosa (Rm. 4:7-8; Mzm. 32:1-2).

Perhatikanlah juga bahwa 'membenarkan orang durhaka' dalam Roma 4:5 sejajar dengan 'memperhitungkan kebenaran bukan berdasarkan perbuatannya' dalam Roma 4:6. Itu berarti bahwa pembenaran sejajar dengan pengimputasian pembenaran. Dalam Roma 4:6 ini kebenaran adalah objek langsung dari 'memperhitung-kan', berbeda dengan ungkapan 'iman diperhitungkan sebagai kebenaran'. Menurut Piper hal ini berarti bahwa menurut Paulus kebenaran diperhitungkan karena iman, bukan bahwa iman diperlakukan sebagai kebenaran di dalam diri kita. ${ }^{34}$ Gundry tidak setuju dengan tafsiran ini. Menurutnya dari Roma 4:6 tidak bisa disimpulkan bahwa iman menjadi sarana, sebab baik kebenaran mau pun iman menjadi objek pengimputasian. Paulus bisa mengatakan, bahwa kepada orang percaya Allah memperhitungkan iman (sebagai kebenaran), dan sekaligus bahwa Allah memperhitungkan kebenaran. 'Allah memperhitungkan baik iman dan kebenaran, sebab Ia memperhitungkan keduanya sebagai identik'. ${ }^{35}$ Gundry juga menunjuk kepada istilah 'kebenaran iman' (dikaiosunē (tēs) pisteōs) (ay. 11, 13). Yang dimaksudkan dengan istilah ini adalah kebenaran yang, karena pengimputasian oleh Allah, terdiri atas iman.

Demikian juga kebenaran dari iman (ek pisteōs) (Rm. 9:30; 10:6) dan kebenaran yang berasal dari Allah berdasarkan iman (Fip. 3:9) adalah iman yang diperhitungkan Allah sebagai kebenaran. Bagi Paulus, 'iman adalah sumber, sarana, dan dasar kebenaran sebab Allah memperhitungkannya sebagai kebenaran'. ${ }^{36}$ Tetapi belum tentu istilah 'kebenaran iman' berarti kebenaran yang terdiri atas iman, sehingga keduanya, kebenaran dan iman, adalah identik. Dalam Roma 4:11, kita membaca: 'Dan tanda sunat itu diterimanya sebagai meterai kebenaran berdasarkan iman yang ditunjukkannya' (LAI). Dalam terjemahan LAI ini kebenaran tidak identik dengan iman. Istilah tēs dikaiosunē tēs pisteōs diparafrase sebagai 'kebenaran bedasarkan iman yang ditunjukkannya'. Moo berpendapat bahwa genitif tēs pisteōs menunjuk kepada sumber: 'kebenaran yang sumbernya adalah iman'. Jadi, Paulus menjelaskan di sini bahwa sunat Abraham meneguhkan statusnya sebagai orang benar. Status ini diperolehnya 'by virtue of his faith' ('berdasarkan imannya'). ${ }^{37}$ Itu berarti bahwa istilah 'kebenaran iman' justru menunjuk kepada iman sebagai sarana pembenaran (lihat terjemahan NIV: 'the righteousness that he had by faith'). Di samping itu, Carson menunjuk kepada konteks ungkapan 'Allah memperhitungkan kebenaran', yaitu konteks kefasikan dan

33 D. A. Carson, "The Vindication of Imputation: On Fields of Discourse and Semantic Fields," in Justification: What's at Stake in the Current Debates, ed. Mark Husbands dan Daniel J. Treier (Downers Grove: InterVarsity Press, 2004), 59-61; lihat juga Moo, The Epistle to the Romans (The New International Commentary on the New Testament), 262.

34 Piper, Counted Righteous in Christ: Should We Abandon the Imputation of Christ's Righteousness?, 58.

35 Gundry, "The Nonimputation of Christ's Righteousness," 25.

36 Gundry, "The Nonimputation of Christ's Righteousness."

${ }^{37}$ Moo, The Epistle to the Romans (The New International Commentary on the New Testament), 269. 
kedurhakaan manusia. Allah memperhitungkan kebenaran kepada kita ketika kita tidak benar. Itu berarti bahwa ungkapan ini tidak persis sama dengan ungkapan 'Allah memperhitungkan iman kepadanya sebagai kebenaran'. ${ }^{38}$

Selanjutnya, Carson menekankan bahwa Paulus dalam Roma 4:23-24 menggambarkan iman sebagai sarana atau syarat pembenaran, sebab apa yang tertulis dalam Kejadian 15:6, yaitu bahwa 'hal itu diperhitungkan kepadanya sebagai kebenaran' (Rm. 4:22), ditulis bagi '(kita) yang percaya' (tois pisteuousin) kepada Dia, yang telah mengbangkitkan Yesus, Tuhan kita, dari antara orang mati (Rm. 4:24). NIV bahkan menerjemahkan 'to whom God will credit righteousness', walaupun kata 'kebenaran' (dikaiosunē) tidak disebut dalam ayat ini, dan walaupun dalam Roma 4:22 tertulis 'hal itu diperhitungkan', yaitu iman. Kita diperhitungkan sebagai orang benar karena iman. Masih ada alasan lagi untuk menafsirkan iman sebagai sarana pembenaran. Sebab dalam Roma 3:27-31 Paulus juga menekankan fungsi iman itu. Dalam 3:28 Paulus menulis: 'Kita dibenarkan oleh iman' (pistei, 3:28; ek pisteōs, dia tēs pisteōs, 3:30). Menurut Carson, fungsi iman sebagai sarana sering ditemukan dalam PB, lihat misalnya Roma 5:1, Filipi 3:8-9, dan Ibrani 11. Sebelum Paulus menulis tentang iman Abraham dalam Roma 4, ia sudah menekankan objek iman Kristen dan dasar pembenaran orang Kristen dalam Roma 3:21-26, dan pentingnya iman sebagai sarana untuk memperoleh kasih karunia dalam Roma 3:27-31.39

Menurut Herman Ridderbos, kita harus memperhatikan bahwa Paulus meletakkan Kejadian 15:6 dalam konteks forensik, walaupun frase 'diperhitungkan sebagai kebenaran' dalam Kejadian 15:6 belum memiliki pengertian forensik imputatif. Berdasarkan pengertian forensik imputatif ini, 'frasa 'diperhitungkan menjadi kebenaran' (Rm. 4) berbicara tentang iman sebagai dasar pengimputasian pembenaran, tetapi dalam pengertian sarana'. ${ }^{40} \mathrm{Hal}$ yang terakhir yang saya sebut dalam rangka diskusi ini adalah objek iman. Dalam Roma 3:21-31, objek iman adalah Yesus, yang ditentukan Allah menjadi jalan pendamaian. Dalam Roma 4, objek iman itu adalah Allah yang dapat melakukan hal-hal mustahil (membenarkan orang durhaka, menghidupkan orang mati, membangkitkan Yesus dari antara orang mati, Rm. 4:5,17,24). Iman diperhitungkan kepada orang percaya sebagai kebenaran karena objeknya ini, yaitu Kristus atau Allah. Sebab oleh karena Abraham penuh keyakinan, 'bahwa Allah berkuasa untuk melaksanakan apa yang telah Ia janjikan', maka 'hal ini diperhitungkan kepadanya sebagai kebenaran' (4:21-22). ${ }^{41}$ Kita sudah melihat bahwa menurut Gundry objek iman tidak menentukan, sebab yang diperhitungkan bukan objek iman (yaitu Kristus, atau Allah), melainkan iman itu sendiri. Walaupun itu benar, namun fakta bahwa iman yang berfokus kepada Kristus atau Allah diperhitungkan kepada kita menunjuk sekali lagi kepada fungsi iman sebagai sarana.

Jadi, kita dapat menyimpulkan bahwa fungsi iman sebagai sarana sangat nyata dalam Roma 3-4, sehingga juga dalam frase 'iman diperhitungkan sebagai kebenaran', iman mempunyai fungsi itu. Belum tentu apa yang dimaksudkan dengan kebenaran: kebenaran Kristus dalam arti ketaatan-Nya yang aktif, atau sesuatu lain. Tetapi tidak mungkin untuk menolak doktrin pengimputasian kebenaran Kristus berdasarkan kutipan Paulus dari Kejadian 15:6 dalam Roma 4.

\footnotetext{
${ }^{38}$ Carson, "The Vindication of Imputation: On Fields of Discourse and Semantic Fields," 64.

39 Ibid., 65.

${ }^{40}$ Herman Ridderbos, p. 181. Lihat seluruh pembahansannya, pp. 179-181. Ridderbos juga menunjuk kepada Filipi 3:9.

${ }^{41}$ Carson, “The Vindication of Imputation: On Fields of Discourse and Semantic Fields," 66-67.
} 


\section{Roma 5:18-19}

Di samping Roma 3-4 masih ada beberapa ayat lain yang penting dalam diskusi ini - dan antara lain Roma 5:18-19, Filipi 3:9, dan 2 Korintus 5:21. Dalam Roma 5:19 kita membaca: 'Sebab itu, sama seperti oleh satu pelanggaran semua orang beroleh penghukuman, demikian pula oleh satu perbuatan kebenaran semua orang beroleh pembenaran untuk hidup. Jadi sama seperti oleh ketidaktaatan satu orang semua orang telah menjadi orang berdosa, demikian pula oleh ketaatan satu orang semua orang menjadi orang benar.' Menurut Hoekema, istilah 'satu perbuatan kebenaran'42 dalam ayat 18 menunjuk kepada ketaatan Kristus yang pasif dan aktif, tetapi karena istilah ini dipertentangkan dengan 'satu pelanggaran', maka yang dimaksudkan pastilah 'ketaatan Kristus terhadap hukum Taurat'. ${ }^{43}$ Selanjutnya, dalam ayat 19 Paulus menggunakan kata kathistēmi, 'mengangkat', 'menempatkan pada status sebagai', yang mengungkapkan suatu ide forensik. Di dalam Adam kita 'telah ditempatkan pada status sebagai orangorang berdosa'. Demikian juga kita yang percaya 'diangkat' sebagai orang benar oleh ketaatan Kristus. Dengan kata-kata lain: kita dinyatakan benar karena ketaatan aktif Kristus telah diperhitungkan kepada kita. ${ }^{44}$

Gundry setuju dengan Hoekema, bahwa kata kerja kathistēmi mengungkapkan suatu ide forensik. Kata kerja ini ditafsirkannya sebagai sinonim dari kata kerja logizomai, dan berarti 'mengangkat sebagai', 'memperhitungkan sebagai'. Tetapi menurut Gundry kata 'ketaatan' dalam ayat 19 menunjuk kepada ketaatan Kristus dalam kematian-Nya yang memperdamaikan (bdk. Flp. 2:8), jadi ketaatan-Nya yang pasif. Hal itu sesuai dengan Roma 3:21-31, di mana kita membaca bahwa oleh kematian Kristus yang memperdamaikan Allah dapat menyatakan benar orang berdosa yang percaya, dan dengan Roma 4, yang mengungkapkan pikiran yang sama dengan frase 'memperhitungkan iman sebagai kebenaran'. Karena ketaatan Kristus 'sampai mati di kayu salib' itu (Flp. 2:8), Allah tetap adil ketika Ia menyatakan benar orang-orang berdosa dengan memperhitungkan iman mereka sebagai kebenaran. ${ }^{45}$

Apakah benar-benar ada alasan-alasan yang kuat untuk menafsirkan 'satu perbuatan kebenaran' (henos dikaiōmatos) ${ }^{46}$ (ay. 18) dan 'ketaatan satu orang' (ay. 19) sebagai ketaatan Kristus yang aktif yang Ia praktekkan sepanjang kehidupan-Nya di bumi ini? Menurut saya interpretasi ini tidak mutlak perlu. Walaupun argumentasi Gundry tidak menentukan, yaitu bahwa pelanggaran dan ketidaktaatan Adam bersifat tunggal, sehingga ketaatan Kristus juga harus merujuk kepada perbuatan tunggal (yaitu kematian-Nya), bukan kepada ketaatan-Nya sepanjang hidup-Nya ${ }^{47}$, namun juga tidak ada bukti bahwa yang dimaksud adalah ketaatan Kristus yang aktif. Ada penafsir yang berbicara tentang 'karya keselamatan Kristus'48, atau tentang 'karya Yesus di kayu salib'

\footnotetext{
${ }^{42}$ Kata dikaiōma dapat diterjemahkan 'perbuatan kebenaran' atau 'perbuatan benar', tetapi juga 'pembenaran' (lihat Rm. 5:16: 'tetapi penganugerahan karunia atas banyak pelanggaran itu mengakibatkan pembenaran'). Menurut Leon Morris (The Epistle to the Romans [PNTC], [Grand Rapids: Eerdmans, 1988], p. 239), kata pembenaran biasanya merujuk kepada pernyataan atau keputusan tertentu, bukan kepada perbuatan, sehingga artinya adalah 'sentence of justification', atau 'justificatory sentence'. Sedangkan Thomas R. Schreiner (Romans [BECNT], [Grand Rapids: Baker Academic, 1998], p. 287) berpegang kepada arti 'righteous conduct', karena paralelisme dengan 'pelanggaran' dan karena kata dikaiōma biasanya berarti 'undang-undang, tuntutan legal, syarat, peraturan'.

43 Hoekema, Diselamatkan Oleh Anugerah (Saved by Grace), 243.

${ }^{44}$ Hoekema, Diselamatkan Oleh Anugerah (Saved by Grace).

45 Gundry, "The Nonimputation of Christ's Righteousness," 26.

46 Dua kata ini juga bisa diterjemahkan 'perbuatan kebenaran satu orang'.

47 Piper, Counted Righteous in Christ: Should We Abandon the Imputation of Christ's Righteousness?, 113-114.

${ }^{48}$ Leon Morris, The Epistle to the Romans [PNTC] (Grand Rapids: Eerdmans, 1988), 240.
} 
sebab ada rujukan kepada Yesaya 53:11 ('dan hamba-Ku itu, sebagai orang yang benar, akan membenarkan banyak orang oleh hikmatnya, dan kejahatan mereka dia pikul').49

Kata kerja kathistēmi pada umumnya berarti 'mengangkat', tetapi juga bisa berarti 'menjadi'. Kata ini mempunyai 'warna' forensik. Bahkan kalau kita menerjemahkan 'menjadi', itu tidak berarti bahwa 'menjadi benar' oleh 'ketaatan satu orang' menunjuk kepada kelakuan benar. Orang-orang yang percaya kepada Yesus 'diangkat' atau 'dijadikan' benar dalam konteks pengadilan sorgawi. ${ }^{50}$ Berdasarkan beberapa pertimbangan di atas, saya menyimpulkan bahwa juga Roma 5:18-19 tidak bisa ditafsirkan sebagai dukungan langsung bagi doktrin pengimputasian ketaatan Kristus yang aktif.

\section{Filipi 3:9}

Oleh karena Dialah aku telah melepaskan semuanya itu dan menganggapnya sampah, supaya aku memperoleh Kristus, dan berada dalam Dia bukan dengan kebenaranku sendiri karena mentaati hukum Taurat, melainkan dengan kebenaran karena kepercayaan kepada Kristus, yaitu kebenaran yang Allah anugerahkan berdasarkan kepercayaan' (Flp. 3:8b-9). Dalam ayat-ayat ini Paulus mengontraskan 'kebenaranku sendiri' yang berasal dari hukum Taurat (tēn ek nomou) dengan 'kebenaran karena kepercayaan kepada Kristus' yang berasal dari Allah (tēn ek theou dikaiosunēn). Istilah yang terakhir ini yang penting. Tentang kebenaran yang kita terima Paulus mengatakan bahwa kebenaran itu berasal dari Allah. Menurut Hoekema, 'kebenaran yang Allah anugerahkan' 'lebih dari sekadar tindakan nonimputasi dosa'. ${ }^{51}$

Piper yakin bahwa kebenaran yang berasal dari Allah adalah kebenaran Kristus, walaupun Paulus tidak menggunakan istilah itu secara eksplisit. Sebab Paulus ingin 'berada dalam Dia' (NIV 'and be found in him'), yaitu Kristus, dan persekutuan trinitaris antara Allah Bapa dan Anak Allah memungkinkan interpretasi 'kebenaran dari Allah' sebagai kebenaran Kristus. ${ }^{52}$ Sebenarnya apakah yang dimaksudkan Paulus dengan 'kebenaran dari Allah' dalam Filipi 3:9? Wright menginterpretasikan istilah 'kebenaran dari Allah' sebagai 'status kebenaran', 'status benar yang berasal dari Allah'. ${ }^{53}$ Menurut Moisés Silva kebenaran ini dianugerahkan oleh Allah, Hakim yang benar. ${ }^{54}$

Apakah konteks menuntut bahwa kebenaran ini adalah ketaatan Kristus yang sempurna terhadap hukum Taurat, yang diimputasikan kepada orang percaya? Memang ada kontras antara 'kebenaran dari hukum Taurat' dan 'kebenaran dari Allah'. Tetapi itu tidak berarti bahwa kebenaran dari Allah itu adalah ketaatan Kristus terhadap hukum Taurat yang diperhitungkan kepada orang percaya. Jelas bahwa kebenaran yang dianugerahkan bukan kebenaran yang terdiri atas iman, tetapi yang datang 'karena iman dalam Kristus' (dia pisteōs Christou) dan 'berdasarkan iman' (epi tēi pistei), dan yang

49 Thomas R. Schreiner, The Epistle to the Romans (Grand Rapids: Baker Academic, 2018), 287; Wright, The Letter to the Romans: Introduction, Commentary, and Reflections, Dalam The New Interpreter's Bible

(Volume X), 529. Hanya Wright menghubungkan ketaatan Kristus dalam Roma 5:19 dengan 'kesetiaan' Yesus yang disebut dalam Roma 3:22. Tetapi tafsiran kata pistis sebagai 'kesetiaan Yesus Kristus' dan bukan sebagai 'iman dalam Yesus Kristus' kurang meyakinkan.

50 Moo, The Epistle to the Romans (The New International Commentary on the New Testament), 345.

'Through Christ's obedient act, people become really righteous; but 'righteous' itself is a legal, not a moral, term in this context.'

${ }^{51}$ Hoekema, Diselamatkan Oleh Anugerah (Saved by Grace), 243.

52 Piper, Counted Righteous in Christ: Should We Abandon the Imputation of Christ's Righteousness?, 84.

53 Wright, Justification: God's Plan \& Paul's Vision, 150-51. Tetapi perhatikanlah bahwa interpretasi Wright mengenai istilah 'status benar' berbeda sekali dengan interpretasi tradisional.

54 Moisés Silva, Philippians (BECNT), second. (Grand Rapids: Baker Academic, 2005), 161. 
bersifat 'asing' bagi manusia, sebab berasal dari Allah. ${ }^{55}$ Jadi, konsep pengimputasian kebenaran yang diajarkan secara langsung dalam Roma 4 tersirat dalam ayat ini. Paulus menekankan bahwa kebenaran kita sendiri berdasarkan hukum Taurat tidak dapat menyelamatkan kita, tetapi Paulus tidak menulis secara langsung bahwa kita memperoleh kebenaran Kristus dalam arti ketaatan-Nya yang sempurna terhadap hukum Taurat.

\section{2 Korintus 5:21}

Dalam 2 Korintus 5:19-21 kita membaca: 'Sebab Allah mendamaikan dunia dengan diri-Nya oleh Kristus dengan tidak memperhitungkan pelanggaran mereka.... Dia yang tidak mengenal dosa telah dibuat-Nya menjadi dosa karena kita, supaya dalam Dia kita dibenarkan oleh Allah.' Pelanggaran mereka tidak diperhitungkan: 'nonimputasi' dosa diajarkan secara langsung dalam ayat 19. Mengapa dosa-dosa tidak diperhitungkan? Sebab Allah telah membuat Kristus, yang tidak mengenal dosa, menjadi dosa karena kita. Paulus tidak menulis secara eksplisit bahwa dosa manusia diperhitungkan kepada Kristus. Tetapi frase bahwa Kristus dibuat Allah menjadi dosa karena kita, yang dapat dihubungkan dengan ajaran Alkitab bahwa Yesus telah mati menggantikan kita, dan menanggung kutuk kita, mengandung arti bahwa dosa kita diperhitungkan kepada Kristus. ${ }^{56}$

Bagian terakhir ayat 21 dapat diterjemahkan sebagai berikut: 'supaya kita menjadi ${ }^{57}$ kebenaran Allah [dikaiosunē theou] di dalam Dia'. Yang menjadi bagian kita, atau dengan bahasa Roma 4, apa yang diperhitungkan kepada kita, adalah 'kebenaran Allah'. Menurut Murray J. Harris, kebenaran Allah di sini adalah 'a right standing before God that God himself bestows'58, lihat juga penjelasan di atas. Walaupun kata 'memperhitungkan' tidak dipakai dalam ayat 21, namun berdasarkan pemakaian kata itu dalam ayat 19 dan simetri antara dua hal yang saling dipertentangkan, yaitu hamartia dan dikaiosune, tidak salah untuk berbicara tentang pengimputasian berganda: dosa diperhitungkan kepada Kristus (ay. 21a), sehingga kebenaran diperhitungkan kepada kita. ${ }^{59}$ Wright memberi tafsiran yang sama sekali berbeda, yaitu bahwa 'kita' menunjuk kepada Paulus dan para rasul lain, dan bahwa istilah 'kebenaran Allah' harus ditafsirkan dalam terang surat Roma, sehingga artinya adalah kesetiaan Allah terhadap perjanjian. ${ }^{60}$ Tetapi menurut Murray J. Harris tafsiran ini merusakkan paralelisme antara hamartia dan dikaiosunē ${ }^{61}$ Selain itu, tidak logis untuk membatasi kata 'kita' kepada Paulus dan pelayanannya. Memang benar bahwa Paulus menulis tentang dirinya sendiri dan pelayanannya dalam 2 Korintus 3-5. Tetapi walaupun kata humeis dalam ayat 21b (supaya di dalam Dia kita telah menjadi 'perwujudan' atau 'penyataan' kebenaran Allah) mungkin secara teoretis dapat diterapkan kepada Paulus dan rekanrekannya, pasti kata humōn dalam ayat 21a (Dia 'telah dibuat-Nya menjadi dosa karena kita') harus diinterpretasi lebih luas. Selain itu, dalam tafsiran Wright ini makna istilah 'di dalam Dia' diperlemah.

\footnotetext{
55 Carson, "The Vindication of Imputation: On Fields of Discourse and Semantic Fields," 69.

56 Ibid. 'It is extraordinarily difficult to avoid the notion of the imputation of our sins to him.'

57 Murray J. Harris, The Second Epistle to the Corinthians (NIGTC) (Grand Rapids: Eerdmans, 2005), 455. Kata kerja ginomai ('menjadi') 'menunjuk kepada perubahan status yang menjadi bagian orang percaya yang berada 'di dalam Kristus' dan merupakan dasar 'ciptaan baru' (v. 17)',

58 Ibid.

59 Ibid. 'As a result of God's imputing to Christ something that was extrinsic to him, namely sin, believers have something imputed to them that was extrinsic to them, namely righteousness.'

60 Wright, Justification: God's Plan \& Paul's Vision, 158-67.

61 Harris, The Second Epistle to the Corinthians (NIGTC), 455-56.
} 
Paulus tidak menulis kebenaran Kristus, tetapi kebenaran Allah. Tetapi menurut Carson hal itu tidak menjadi masalah, sebab dalam ayat 19 kita membaca bahwa 'Allah mendamaikan dunia dengan diri-Nya oleh Kristus'. Kebenaran Allah itu direalisasikan melalui Kristus, dan juga menjadi bagian kita melalui Kristus ('di dalam Dia'), yaitu dalam kesatuan dengan Kristus (bdk. Flp. 3:8-9 dan 1 Kor. 1:30) ${ }^{62}$. Jadi, kebenaran yang diperhitungkan kepada kita bukan saja kebenaran Allah, melainkan juga kebenaran Kristus. ${ }^{63}$ Pendapat Carson ini dapat diterima. Kita tidak boleh menafsirkan istilah kebenaran Allah (2 Kor. 5:21) atau kebenaran yang berasal dari Allah (Flp. 3:9) seolaholah itu kebenaran yang tidak berasal dari Kristus. Sebab dalam seluruh PB jelas bahwa kebenaran itu dikerjakan oleh Kristus, atau dianugerahkan kepada orang percaya berdasarkan karya Kristus di kayu salib. Namun juga dalam 1 Korintus 5:21 tidak ada ajaran langsung mengenai kebenaran (Kristus) itu sebagai ketaatan Kristus yang aktif.

\section{Kesimpulan}

Masih ada nas-nas lain yang bisa dibahas dalam rangka pokok ini, seperti 1 Korintus 1:30 dan Roma 10:4. Tetapi nas-nas yang telah dibicarakan di atas memberi dasar yang secukupnya untuk menarik beberapa kesimpulan. Pertama-tama, pengimputasian kebenaran, tanpa penjelasan lebih lanjut mengenai kebenaran itu, diajarkan oleh Roma 4 belum tentu kebenaran seperti apa atau kebenaran siapa yang dimaksudkan, tetapi jelas bahwa kebenaran diperhitungkan kepada orang percaya. Bukan saja dalam Roma 4:6,11, tetapi juga dalam frase 'iman diperhitungkan sebagai kebenaran', kita menemukan iman sebagai sarana pengimputasian kebenaran itu. Dalam Roma 4 kebenaran yang diperhitungkan kepada orang percaya tidak dijelaskan lebih lanjut. Tetapi dalam Filipi 3:9 dan 2 Korintus 5:21 kita menemukan istilah 'kebenaran Allah' dan 'kebenaran yang berasal dari Allah'. Kedua nas ini memberi dukungan bagi istilah dogmatis iustitia aliena, kebenaran 'asing', yang bukan berasal dari orang percaya sendiri. Seperti diuraikan di atas, tidak ada keberatan untuk berbicara tentang kebenaran Kristus berdasarkan kedua ayat tersebut. Dua istilah yang kita temukan dalam Roma 5:18-19, yaitu 'satu perbuatan kebenaran' (ay. 18) dan 'ketaatan satu orang' (ay. 19), menunjuk kepada karya Kristus sebagai keseluruhan. Hoekema menerapkan kedua istilah ini secara khusus kepada ketaatan Kristus yang aktif, tetapi menurut saya tafsiran ayat-ayat ini tidak menuntut penerapan ini. Hoekema sendiri menyatakan bahwa istilah 'satu perbuatan kebenaran' menunjuk kepada 'keseluruhan ketaatan Kristus'.64

Berdasarkan nas-nas yang dibahas dalam tulisan ini dapat dikatakan bahwa, walaupun Alkitab tidak mengajarkan secara langsung dan eksplisit bahwa kebenaran Kristus diperhitungkan kepada kita, namun jelaslah bahwa secara implisit hal ini merupakan ajaran Alkitab yang sah. Terutama kesatuan orang percaya dengan Kristus sangat menentukan di sini. Tetapi kebenaran Kristus harus dimengerti sebagai seluruh ketaatan Kristus, dan terutama yang dalam dogmatika disebut ketaatan-Nya yang pasif, atau dalam rumusan Hoekema 'ketaatan penderitaan'.65 Ketaatan Kristus yang aktif,

\footnotetext{
62 Carson, "The Vindication of Imputation: On Fields of Discourse and Semantic Fields," 72. Carson menekankan bahwa dalam surat-surat Paulus pembenaran dikaitkan erat dengan kesatuan kita dengan Kristus. Dalam Filipi 3:8-9 Paulus menulis bahwa ia ingin 'berada dalam Dia'. Dalam 1 Korintus 1:30 kita membaca bahwa kita berada dalam Kristus Yesus, yang oleh Allah telah menjadi hikmat bagi kita', dan kebenaran (dikaiosunē), kekudusan, dan penebusan.

63 Ibid., 69-71. 'It is difficult to imagine why this righteousness should be understood to be 'the righteousness of God' and not the righteousness of Christ.'

64 Hoekema, Diselamatkan Oleh Anugerah (Saved by Grace), 243.

65 Ibid., 240.
} 
yaitu ketaatan-Nya yang sempurna terhadap hukum Taurat, juga tersirat dalam istilah kebenaran Kristus, tetapi lebih berdasarkan penalaran dogmatis daripada ajaran langsung di dalam Alkitab. ${ }^{66}$ Namun penalaran dogmatis itu berdasarkan ajaran Alkitab. Saya tidak akan membicarakan hal ini, sebab pembahasan dogmatis itu bukan tujuan dari tulisan ini, dan pembahasan seperti itu membutuhkan satu tulisan (penelitian) tersendiri sendiri. Sebagai penutup, saya mengutip kata-kata Katekismus Heidelberg Mi. 23, p/j. 60, yang menjelaskan pembe-naran oleh iman sebagai berikut:

'Namun, Allah, tanpa jasa apa pun dari pihakku, semata-mata berdasarkan rahmat, memberikan kepadaku anugerah ini: pelaksanaan pelunasan oleh Kristus, kebenaran-Nya, dan kesucian-Nya yang sempurna dianggap-Nya sebagai milikku, seolah-olah aku belum pernah dihinggapi dosa atau berbuat dosa, bahkan seolaholah aku sendirilah yang mengerjakan segala ketaatan yang dikerjakan oleh Kristus untukku, asal saja anugerah itu kuterima dengan hati yang percaya.' 


\section{Referensi}

Calvin, John. Institutes of the Christian Religion, Buku III. Xi. 2., n.d.

Carson, D. A. "The Vindication of Imputation: On Fields of Discourse and Semantic Fields." In Justification: What's at Stake in the Current Debates, edited by Mark Husbands dan Daniel J. Treier. Downers Grove: InterVarsity Press, 2004.

Gundry, Robert H. "The Nonimputation of Christ's Righteousness." In Justification: What's at Stake in the Current Debates, edited by Mark Husbands and Daniel J. Treier. Downers Grove: InterVarsity Press, 2004.

Harris, Murray J. The Second Epistle to the Corinthians (NIGTC). Grand Rapids: Eerdmans, 2005.

Hoekema, Anthony A. Diselamatkan Oleh Anugerah (Saved by Grace). Revisi. Surabaya: Momentum, 2006.

James D. G. Dunn. Romans 1-8 (Word Biblical Commentary 38a/B). Dallas: Word Books, 1988.

James D. G. Dunn and Alan M. Suggate. The Justice of God: A Fresh Look at the Old Doctrine of Justification by Faith. Grand Rapids: Eerdmans, 1993.

McCormack, Bruce L. What's at Stake in Current Debates over Justification, 2003.

McGrath, Alister E. Iustitia Dei: A History of the Christian Doctrine of Justification (Third Edition). Cambridge: Cambridge University Press, 2005.

Moo, Douglas J. The Epistle to the Romans (The New International Commentary on the New Testament). Grand Rapids: Eerdmans, 1996.

Morris, Leon. The Epistle to the Romans [PNTC]. Grand Rapids: Eerdmans, 1988.

Piper, John. Counted Righteous in Christ: Should We Abandon the Imputation of Christ's Righteousness? Wheaton: Crossway Books, 2002.

- - - The Future of Justification: A Response to N. T. Wright. Wheaton: Crossway Books, 2007.

Schreiner, Thomas R. The Epistle to the Romans. Grand Rapids: Baker Academic, 2018.

Silva, Moisés. Philippians (BECNT). Second. Grand Rapids: Baker Academic, 2005.

Wright, N. T. Justification: God's Plan \& Paul's Vision. Downers Grove: IVP Academic, 2009.

- - _. "New Perspectives on Paul." In Justification in Perspective: Historical Developments and Contemporary Challenges, edited by Bruce L. McCormack. Grand Rapids: Baker Academic, 2006.

- - - The Letter to the Romans: Introduction, Commentary, and Reflections, Dalam The New Interpreter's Bible (Volume X). Nashville: Abingdon Press, 2002. 